\title{
Influence of the addition of chitin nanocrystals on the characteristics of cellulose acetate films
}

\author{
Preethi Ravikumar') (ORCID ID: 0000-0001-7578-4549), Suresh Sagadevan" ${ }^{2), *)}$ (0000-0003-0393-7344) \\ DOI: dx.doi.org/10.14314/polimery.2021.2.2
}

\begin{abstract}
The present study deals with chitin nanocrystal (CHNC)-reinforced cellulose acetate (CA) films formed by the solvent casting method that makes use of poly(ethylene glycol) (PEG) as a plasticizing agent. Three different films containing various mass ratios of CHNCs $(0.5,1$, and 2 wt \%) in CA were investigated for hydrophilicity, mechanical properties, soil degradation, strength, water solubility, light transmittance, and antifungal activity. From the FT-IR analysis, no detectable shifts to the cellulose acetate bands with the loading of small amounts of CHNCs were observed. However, the light transmittance capacity of CA films decreased due to chitin addition. The chitosan incorporation enhanced the hydrophilic character of CA films, and also, the mechanical properties of the lower percentage of CHNCs in CA, like Young's modulus, had a slight positive effect, while the tensile strength and elongation at breaks - had a negative influence. Finally, an increasing trend of antifungal activity with that of increased CHNC content was observed, i.e., the $2 \mathrm{wt} \%$ CHNCs containing CA film showed an inhibition rate (FGI) of $35 \%, 1 \mathrm{wt} \%$ CHNCs had a $15 \%$ inhibition rate, which is higher than that of $0.5 \mathrm{wt} \% \mathrm{CHNCs}$ and pure $\mathrm{CA}$, thereby indicating the potential role of CHNCs-reinforced CA films for packaging applications.
\end{abstract}

Keywords: cellulose acetate, chitin nanocrystals, mechanical properties, antifungal activity, water solubility, light transmittance capacity.

\section{Wpływ dodatku nanokrystalicznej chityny na właściwości folii z octanu celulozy}

Streszczenie: Metodą odlewania rozpuszczalnikowego otrzymano biodegradowalne folie z octanu celulozy (CA) z dodatkiem 0,5; 1 i 2\% mas. nanokrystalicznej chityny (CHNC) i poli(glikolu etylenowego) jako plastyfikatora. Zbadano hydrofilowość, właściwości mechaniczne, zdolność do degradacji w glebie, rozpuszczalność w wodzie, przepuszczalność światła i aktywność przeciwgrzybiczną folii. Przy niewielkiej zawartości CHNC nie stwierdzono przesunięcia pasm charakterystycznych w widmach FT-IR. Modyfikowane folie CA charakteryzowały się mniejszą przepuszczalnością światła i większą hydrofilowością (mniejsza wartość kąta zwilżania). Dodatek 0,5\% mas. CHNC w niewielkim stopniu zwiększał moduł Younga oraz zmniejszał wytrzymałość na rozciąganie i wydłużenie przy zerwaniu. Stwierdzono korzystny wpływ CHNC na stopień hamowania wzrostu grzybów (wskaźnik FGI). Przy zawartości $1 \%$ mas. CHNC wskaźnik ten wynosił $15 \%$, a przy zawartości $2 \%$ mas. $35 \%$ i był wyższy niż dla octanu celulozy $(F G I=7,5 \%)$. Wzmocnione $C H N C$ folie CA mogą znaleźć zastosowanie w przemyśle opakowaniowym.

Słowa kluczowe: octan celulozy, chityna nanokrystaliczna, aktywność przeciwgrzybiczna, rozpuszczalność w wodzie, zdolność przepuszczania światła.

The recent increase in the use of natural polymers for biocomposite production is because of many interesting features like non-toxicity, biodegradability, biocompatibility, high reactivity, abundancy, and cost-effectiveness

\footnotetext{
1) Kaunas University of Technology, Faculty of Chemical Technology, Department of Environmental Engineering, Radvilènų pl., 19-236 Kaunas, Lithuania.

2) University of Malaya, Nanotechnology \& Catalysis Research Centre, Kuala Lumpur 50603, Malaysia.

*) Author for correspondence: drsureshnano@gmail.com
}

where they all can bring about technological advances and at the same time avoid environmental concerns [1, 2]. Included among various kinds of natural polymers is a typical ester derivative, cellulose acetate (CA), which is formed by the partial or complete modification of hydroxyl groups of glucose units in cellulose with that of acetyl groups. The advantage of incorporating CA in the biocomposite/bioplastic formation is that it can be easily transformed into many different shapes including fibers, films, and membranes from either liquid or semi-liquid forms [3]. Since the membranes formed with CA maintain 
high hydrophilic abilities, they resist protein fouling and provide an eco-friendly behavior so that they can be used for applications in water treatment [4]. Although the composites formed with CA have many different industrial applications, the compound still suffers from the limitations of low stability in its natural form, mechanical resistance, and reduced adsorption levels [5]. To overcome such limitations of CA, it has been reinforced or loaded with other structurally similar and naturally occurring plant or animal derived products like chitin, chitosan, etc. [6]. The alterations occurring to the in-built properties of CA followed by the fiber reinforcement like aspect ratio and pore dimensions can bring about significant improvements in geometry and mechanical percolation [7]. As an example, the composite formed by the combination of CA and chitin nanocrystals (CHNCs) using an electrospinning technique investigated anti-fouling properties along with super hydrophilic surface transition and thus found an application as a water purifier in the food industry to avoid contaminants [8].

Chitin is a common marine polysaccharide obtained from fungal cell walls, yeast, arthropod exoskeletons, crustacean shells, etc., and plays a significant role as a biopolymer in various chemical and biological processes [6, 9, 10]. Reinforcement with CHNCs [11] has been tested along with other polymer matrices including alginate [12], polycaprolactone [13], poly(S-co-BuA) [14], rubber [15], poly(vinyl alcohol) [16], soy protein isolate plastics [17], starch [18] and chitosan [19]. Besides taking advantage of the "green" biodegradable and biocompatible filler properties of CHNCs, they have been employed in food packaging to nullify the negative effects of silver nanoparticles on humans [20]. Apart from the advantages, CHNCs possesses a self-aggregation property which leads to poor efficiency in nanocomposites and, to avoid that, plasticizers are used [11]. Among many different plasticizers, poly(ethylene glycol) (PEG) is a naturally derived one and the biocomposite films formed with this plasticizer avoid brittleness and have increased water vapor permeability and hydrophilicity [21, 22].

By taking into consideration the individual properties offered by CA and chitin, the present study deals with CHNC reinforced CA films that make use of PEG plasticizer in a solvent casting technique. For the testing, three different composite films with varied concentrations of CHNCs $(0.5,1$, and 2 wt \%) were produced and we further investigated the physicochemical, mechanical, and antifungal properties to be useful as a packaging material at the industrial level.

\section{EXPERIMENTAL PART}

\section{Materials}

Cellulose acetate (CA, $M_{n} 30$ 000) and acetone analysis grade were purchased from Sigma Aldrich, USA. Glacial acetic acid and poly(ethylene glycol) (PEG, $M_{n}$
400) were purchased from Panreac. Potato dextrose agar was obtained from Scharlau. All chemicals were used without any further purification.

Alpha chitin and alpha chitin nanocrystals were isolated from lobster waste by simply following the earlier reported method [23]. Chitin nanocrystals (CHNCs) were produced by acid hydrolysis $[8,24]$ and for that, about $5 \mathrm{~g}$ of chitin flakes were bleached and deproteinized before undergoing hydrolysis with $3 \mathrm{M} \mathrm{HCl}$ for $90 \mathrm{~min}$ at $80^{\circ} \mathrm{C}$. After completion of the hydrolysis, the muddy remains were centrifuged to remove the unused acid and preserve the thick supernatant, CHNCs. To achieve the neutral $\mathrm{pH}$ of CHNCs, the supernatant was dialyzed using distilled water (supernatant was resuspended in $300 \mathrm{~cm}^{3}$ distilled water and dialyzed using dialysis membrane with $12000 \mathrm{~g} / \mathrm{mol}$ molecular weight cut-off under room temperature for 4 days) and sonicated to separate the clumps to attain individual nanocrystals before storing (the supernatant was sonicated with maximum amplitude of $40 \%$ for a total operating time of $20 \mathrm{~min}$ with every $5 \mathrm{~min}$ of sonication cycle undergoing $5 \mathrm{~min}$ interval between alternating cycles to attain individual nanocrystal using QSonica Sonicator, $700 \mathrm{~W}$ ). Various mass proportions of CHNCs, i.e., 0.5, 1, and 2 wt \% were impregnated into $\mathrm{CA}$ by mixing, followed by sonication. The initial concentration of CHNCs was found to be associated with $76.23 \%$ water.

\section{Preparation of films}

About $5.5 \mathrm{~g}$ of CA was dissolved in a solvent mixture consisting of $25 \mathrm{~cm}^{3}$ acetic acid and $25 \mathrm{~cm}^{3}$ of acetone and to this, $13.2 \mathrm{~cm}^{3}$ (30\%) of PEG was added as a plasticizer. To ensure the complete mixing of all components, the mixture was stirred overnight (12 h) [24] and after this period, the obtained mixture was used for the formation of four different films. The first film sample was prepared without any CHNCs but contained $10 \mathrm{~cm}^{3} \mathrm{CA}$ solution only (pure $\mathrm{CA}$ ); the $2^{\text {nd }}$ film sample was prepared with $0.5 \mathrm{wt} \% \mathrm{CHNCs}$ in $10 \mathrm{~cm}^{3} \mathrm{CA}$ solution (CA/CHNC $0.5 \%)$. The $3^{\text {rd }}$ film sample was prepared with 1 wt $\%$ CHNCs in $10 \mathrm{~cm}^{3}$ CA solution (CA/CHNC 1\%), while the $4^{\text {th }}$ film sample was prepared with $2 \mathrm{wt} \%$ of CHNCs in 10 $\mathrm{cm}^{3} \mathrm{CA}$ solution (CA/CHNC $2 \%$ ). The increasing percentage of CHNCs in CA were homogenized separately for each percentage (Heidolph, Silent Crusher M) for $10 \mathrm{~min}$ at $12000 \mathrm{rpm}$ until no traces of CHNCs were found in the solution. The homogenized sample was poured into glass Petri plates and allowed to dry for $24 \mathrm{~h}$ at $30^{\circ} \mathrm{C}$ temperature, where the film thickness was measured using a digital micrometer (Mitutoyo, China).

\section{Methods of testing}

- Fourier transform infrared (FT-IR) spectra were recorded on a Perkin-Elmer spectrometer equipped with Universal Attenuated Total Reflectance accessory with 
an internal reflection diamond crystal lens. The defined range was from 650 to $4000 \mathrm{~cm}^{-1}$ with a resolution of $4 \mathrm{~cm}^{-1}$ and 8 scans.

- The light transmittance spectra of the formed biocomposite films were measured at room temperature in the spectral range of 400-700 $\mathrm{nm}$ using a Shimadzu UV-3600 UV-VIS-NIR spectrophotometer.

- The contact angle measurements for the evaluation of changes in the hydrophilic character of CA/CHNCs films were performed by taking small film samples at room temperature and, for that, the Data physics OCA20 Contact Angle System was employed. By using a syringe with a needle, distilled water was delivered dropwise on the film sample and three different measurements of the film's contact angle were recorded by varying the positions.

- Gravimetrically, water solubility testing was performed using the film samples that were cut into small pieces of $2 \times 3\left(\mathrm{~cm}^{2}\right)$ size and placed in Petri plates containing $20 \mathrm{~cm}^{3}$ water. The test was carried out at room temperature $\left(25 \pm 1^{\circ} \mathrm{C}\right)$ and consecutively noted the initial dry mass of samples and the $24 \mathrm{~h}$ immersion of film samples followed by the drying at $60^{\circ} \mathrm{C}$ for another $24 \mathrm{~h}$. The procedure was repeated thrice, and the final dry mass of films was presented as total soluble matter (TSM) in percentage by the equation,

$\operatorname{TSM}(\%)=[($ Initial dry mass - final dry mass $) /$ Initial dry mass] $\times 100 \%$

- The dry films were cut into small pieces $\left[2 \times 3\left(\mathrm{~cm}^{2}\right)\right]$ and weighed accordingly. The films were placed into enriched soil and watered daily $\left(10 \mathrm{~cm}^{3}\right)$ for $30-60$ days. The final mass of the films was recorded. In order to maintain a natural biodegradable environment, the soil microflora was not altered. The microorganisms in the soil were activated via adding water. The final mass revealed the biodegradability range of film samples in the natural environment.

- The tensile tests were performed under ambient conditions using a Material Testing Systems (MTS Insight 10) device having a load cell of $250 \mathrm{~N}$ and a deformation rate of $3 \mathrm{~mm} / \mathrm{min}$ (gauge length of $10 \mathrm{~mm}$ ). The tensile strength, tensile modulus, and elongation at break were calculated using MTS Test Works 4 software. The results presented were the average of 10 determinations.

- The antifungal activity of synthesized film was determined using the mold Aspergillus niger (A. niger) Tiegh (MB284309) (CBS-KNAW, Holland) so as to investigate the influence of $\mathrm{CHNCs}$ on the CA film. In the solid substrate of potato dextrose agar (Sharlau), A. niger was previously cultured and incubated for $72 \mathrm{~h}$ at $25 \pm 1.5^{\circ} \mathrm{C}$ in sealed Petri dishes within a Selecta Medilow climatic chamber. An aliquot of spores was diluted after growing in Ringer solution and aseptically inoculated on the surface containing the film by using a spray $\left(0.04 \mathrm{~cm}^{3}\right.$ of dissolution at $\left.1.05 \cdot 10^{6} \mathrm{spores} / \mathrm{cm}^{3}\right)$. After incubation for 7 days at $25 \pm 1.5^{\circ} \mathrm{C}$, the films were gently extracted from the agar and washed with Ringer solution. The obtained spore solution was vortexed and stained with LPCB (Lactophenol Cotton Blue) to count the spore's concentrations and using a trypan blue solution for the viability analysis. The concentration of the cells was determined using a Cellometer ${ }^{\circledR}$ Mini (Nexcelom Bioscience LLC) automated cell counter by placing $0.020 \mathrm{~cm}^{3}$ of each spore solution inside a Cellometer ${ }^{\circledR}$ Counting Chamber and using Cellometer ${ }^{\circledR}$ Mini software for the analysis. The average of three independent experiments corresponds to the concentration of each sample. The fungal growth inhibition (FGI, \%) was calculated as the concentration of spores (conidia) per milliliter, by the following equation:

$$
\text { FGI \% }=100 \times\left(C_{g}-T_{g}\right) / C_{g}
$$

where, $C_{g}$ - the average concentration of the control set (A. niger only), $T_{g}$ - the average concentration in different sets of the film.

\section{RESULTS AND DISCUSSION}

\section{Measurement of film thickness}

After $24 \mathrm{~h}$ of drying, the films were removed from the Petri plates, and the thickness was measured using a micrometer, while the appearance and transparency were observed visually. The thickness of pure CA film was found to be $0.298 \mu \mathrm{m}, \mathrm{CA} / \mathrm{CHNC} 0.5 \%$ was $0.277 \mu \mathrm{m}$, $\mathrm{CA} / \mathrm{CHNC} 1 \%$ was $0.223 \mu \mathrm{m}$, and CA/CHNC $2 \%$ was $0.254 \mu \mathrm{m}$. The visual observation of all the CA/CHNCs films indicated that they were transparent with a pale milkish white color.

\section{FT-IR analysis}

Figure 1 shows the comparison of FT-IR spectra of pure $\mathrm{CA}, \mathrm{CA} / \mathrm{CHNC} 0.5 \%, \mathrm{CA} / \mathrm{CHNC} 1 \%$, and CA/CHNC $2 \%$ films. From the spectral bands, the characteristic absorption peak of chitin (in CHNCs), as well as $\mathrm{NH}$ and $\mathrm{OH}$ stretching, occurred at $3434 \mathrm{~cm}^{-1}$. The divided peaks around $1656-1618 \mathrm{~cm}^{-1}$ can be attributed to the amide I region, while the peak at $1552 \mathrm{~cm}^{-1}$ can be linked to the amide II spectral region. However, the upcoming signal at $1530 \mathrm{~cm}^{-1}$ of protein would result in absorption [25] and the CA sample seems to have undergone a higher acetylation degree with a lower bandwidth as observed by the band at $3442 \mathrm{~cm}^{-1}$, i.e., due to the $-\mathrm{OH}$ group. The partial cellulose acetylation at $3442 \mathrm{~cm}^{-1}$ indicates a decreased intensity of the sample. The CA absorption peak at $1742 \mathrm{~cm}^{-1}$ relates to the vibration of carbonyl groups in -COOR and an ether group was encountered at $1644 \mathrm{~cm}^{-1}$. No new peaks were formed, and observable changes were not seen after the addition of $0.5,1$, and $2 \mathrm{wt} \% \mathrm{CHNCs}$ to the CA matrix and this means that, no chemical changes occurred to the structure of CA due to the incorporation of a small fraction of CHNCs into the matrices of CA. 


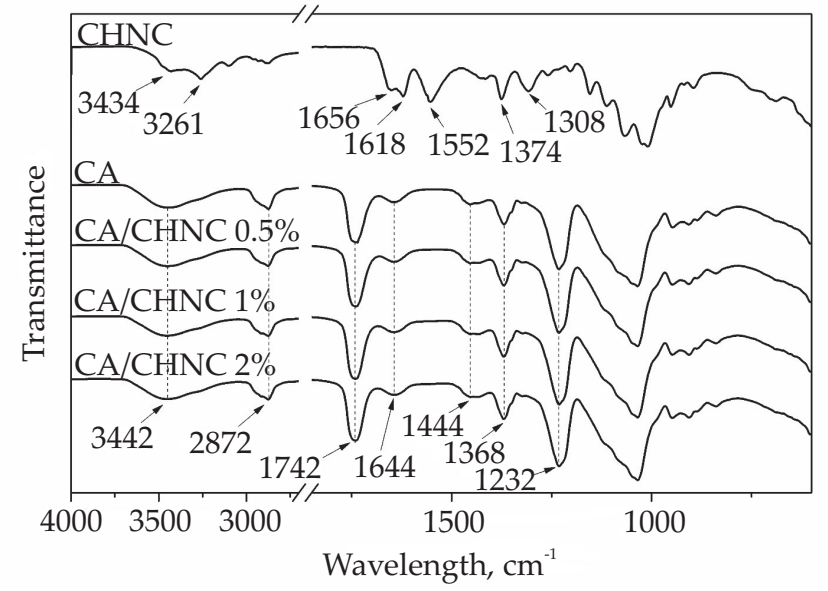

Fig. 1. The FT-IR spectra of CA, CA/CHNC $0.5 \%$, CA/CHNC $1 \%$, CA/CHNC $2 \%$

\section{Optical transmittance}

The transmittance spectra of each film was measured in the visible spectral range $(400-700 \mathrm{~nm})$ at room temperature as shown in Fig. 2 where the optical spectral values provide information about the complete dispersion of filler (CHNCs) in the matrix of CA [26]. The addition of $0.5 \mathrm{wt} \%$, CHNCs into CA not only decreased the amount of light transmitted but also reduced the transparency of CA films. All the films were less transparent than the pure CA film, which transmitted $21 \%$ of the light in the visible region.

\section{Water solubility testing}

The water solubility of CA/CHNCs film was illustrated in Fig. 3. All the films, with or without CHNCs in CA, achieved higher TSM\%. The pure CA film had

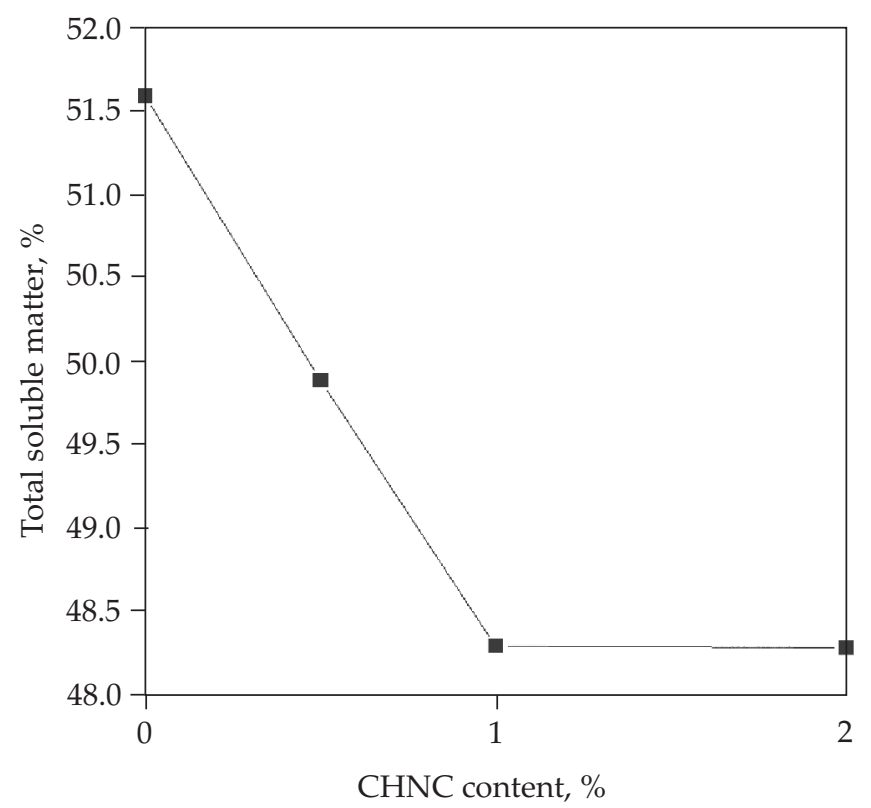

Fig. 3. Total soluble matter (TSM\%) of CA, CA/CHNC $0.5 \%$, CA/CHNC 1\%, CA/CHNC $2 \%$

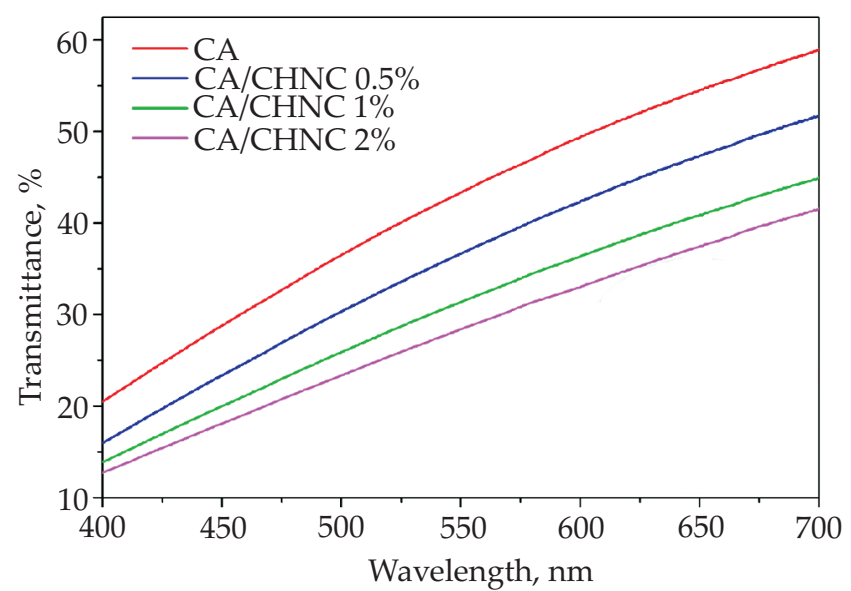

Fig. 2. Optical transmittance spectra for CA, CA/CHNC $0.5 \%$, CA/CHNC 1\%, CA/CHNC $2 \%$

the highest $T S M \%$ of $51.5 \%$, which gradually reduced to $49.8,48.2$, and $48.2 \%$ due to the addition of $0.5,1$, and 2 wt \% (respectively) of CHNCs into the CA matrices. Although the TSM\% of the films decreased gradually, there was no significant loss observed. An increasing fraction of CHNCs in CA decreased the solubility level of films; however, after 6 days of water solubility testing, the films appeared shrunk and became brittle with an absolute loss in weight percentage.

\section{Mechanical properties}

The elastic modulus, tensile strength, and elongation at break of each film are shown in Fig. 4, where a substantial increase in the amount of CHNCs in the CA film revealed a positive impact on the Young's modulus and negative impact on tensile strength and elongation at break of the film samples. The elastic modulus of $\mathrm{CA} / \mathrm{CHNC}$ films increased compared to pure CA film. The tensile strength of $\mathrm{CA} / \mathrm{CHNC} 2 \%$ film is similar to the control film, while the elongation at break of $\mathrm{CA} / \mathrm{CHNC}$ films showed a gradual decline to that of the control film. The decrease in the mechanical strength of $\mathrm{CA} / \mathrm{CHNC}$ films can be due to the
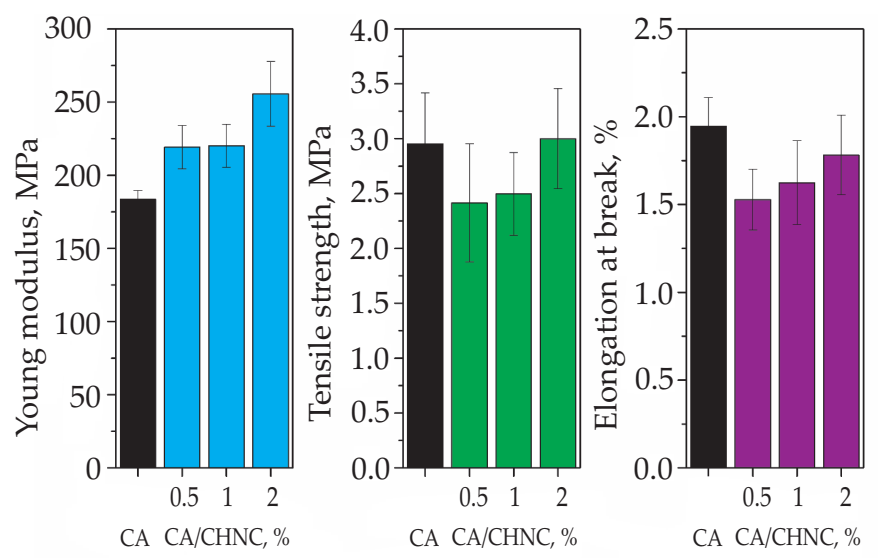

Fig. 4. Mechanical properties of CA, CA/CHNC $0.5 \%, \mathrm{CA} / \mathrm{CHNC} 1 \%$, CA/CHNC $2 \%$ 


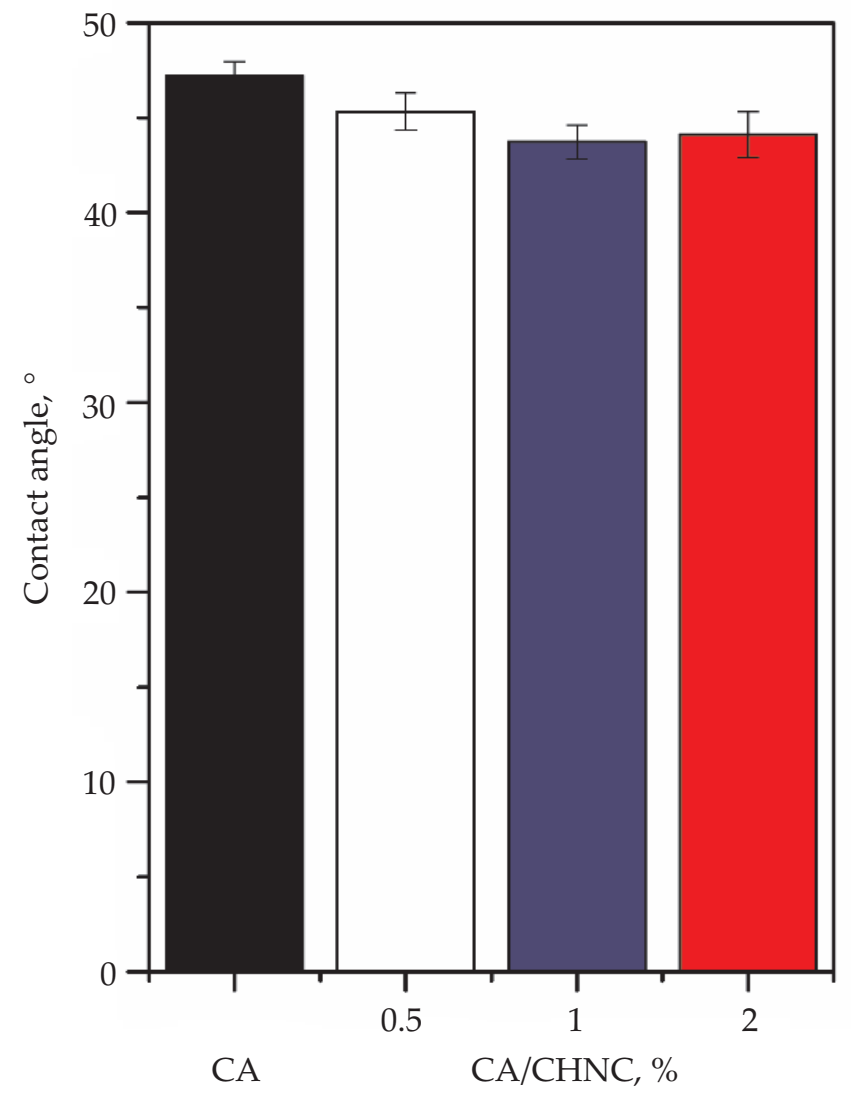

Fig. 5. Contact angle analysis of CA, CA/CHNC $0.5 \%, \mathrm{CA} / \mathrm{CHNC} 1 \%$, CA/CHNC $2 \%$

irregular adhesion between CHNCs and CA [27]. On the other hand, the formation of fragile components can be due to the addition of filler (CHNCs), which is attributed to the brittleness of the films [28]. This may be due to lower fractions of CHNCs in CA and can be overcome with the use of higher fractions of CHNCs embedded in the CA matrix.

\section{Soil degradation}

A novel study done by researchers revealed that CA fibers were partially degraded in 2 months in moist soil and completely degraded over 4-9 months [29]. In the present study, the CA films reinforced with $0.5,1,2 \mathrm{wt} \%$ CHNCs were placed in soil for 1-2 months. After 30 days, the films weighed slightly less than the initial film weights. After 60 days, the films were almost half the initial weight, which means that the films are biodegradable under a natural environment in a short period. But the incorporation of CHNCs into CA decreased degradation.

\section{Contact angle analysis}

The hydrophilic property of the films was characterized by the measured contact angle of the film surface; it was less than $90^{\circ}$ [30]. The basic information of hydrophilicity of the prepared films given by the contact angle measurements is shown in Fig. 5. All the films seem to be hydrophilic during the initial stages and this hydro-

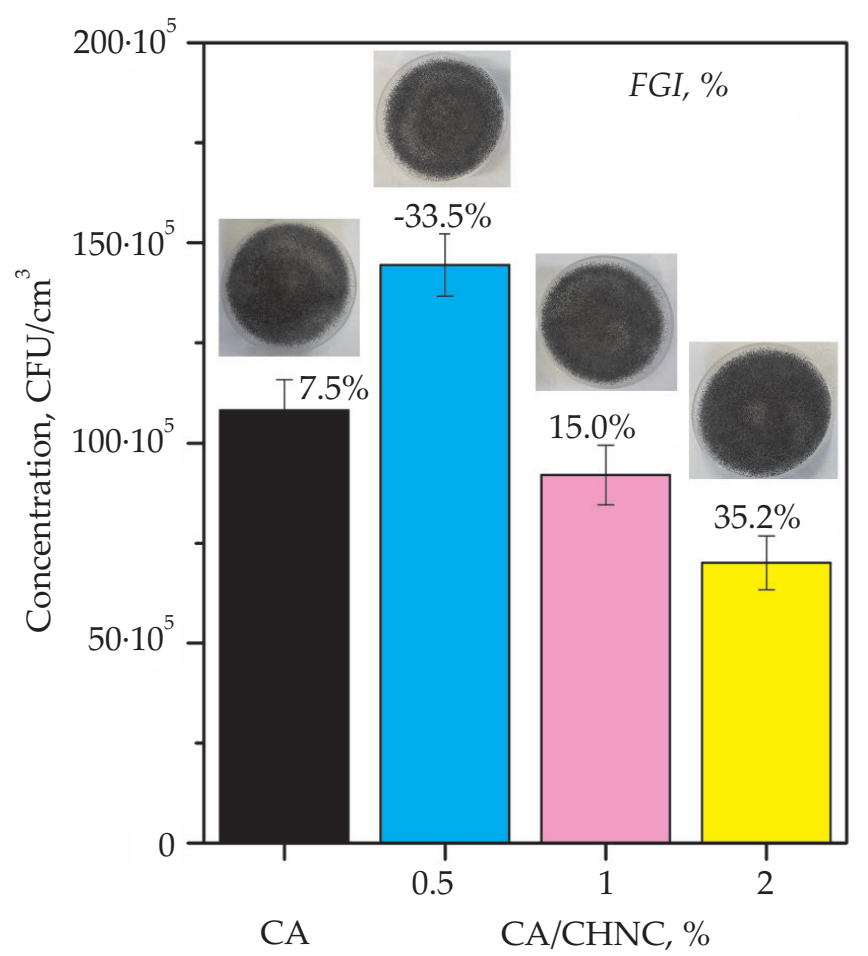

Fig. 6. Anti-fungal activities of: CA, CA/CHNC $0.5 \%, \mathrm{CA} / \mathrm{CHNC} 1 \%$, CA/CHNC $2 \%$ films expressed as inhibition zone diameter $(\mathrm{mm})$

philicity of the samples can be attributed to CA and the presence of plasticizer [22]. The CA film had high hydrophilicity (of $48^{\circ}$ ), but the addition of varying fractions of CHNCs into CA decreased the hydrophilicity of the prepared films. The reduction of contact angle values was mainly due to the CHNC's chemical structure alteration on the surface of CA [31]. An increase in unsubstituted groups of $\mathrm{OH}$ subsequently decreased the contact angle of the samples [32]. Thus, a substantial increase of CHNCs in the CA matrix affected the membrane surface.

\section{Antifungal activity}

The antifungal activity of biocomposites was conducted to determine the effect of CHNCs on CA films. In this case, CA was mixed with $0.5,1$, and 2 wt $\%$ of CHNCs and exposed to the action of $A$. niger. Even though the antimicrobial activity of chitin and chitosan were outstanding against bacteria and fungi, a few facts are unknown or hidden [33]. As shown in Fig. 6, a significant difference was observed, i.e., the antifungal inhibition of composite films increased with a higher percentage of CHNCs in the CA matrices. We found that the CA/CHNC $0.5 \%$ sample restricted more fungus cell units per millimeter than that of the pure CA sample, while the CA/CHNC $1 \%$ and $\mathrm{CA} / \mathrm{CHNC} 2 \%$ showed considerable inhibition rates compared to that of $\mathrm{CA} / \mathrm{CHNC} 0.5 \%$. The considerable increase in the fungicidal action of $2 \mathrm{wt} \% \mathrm{CHNCs}$ is due to the availability of more amino groups to support the interaction of CHNCs with the fungal surface [23]. There 
have been many literature studies indicating the fungicidal and antimicrobial activity of chitin and chitosanbased composites [33-35]. Also, few other works show differences between CHNCs and chitin nanofiber fungicidal activity [36], and this is the first report dealing with the inhibiting action of CHNCs and CA in a single composite.

\section{CONCLUSION}

The CA matrices with small fractions of CHNCs and varying concentrations $(0.5,1$, and 2 wt \%) were prepared using the solvent casting technique to investigate the influence of chitin reinforcement towards the physicochemical, mechanical, and biological properties. The formed films were found to be hydrophilic and showed considerable improvement in the antifungal activity and Young's modulus values by the addition of a 0.5 wt \% increasing fraction of CHNCs. Also, the water solubility of the films decreased slightly. Slight changes were observed in a few of the results mentioned above, which may contribute to the packaging application due to an increase in the characterized values by the addition of CHNCs. To conclude, the solvent casting of CA with 0.5 , 1, and 2 wt \% CHNCs didn't pave the way for considerable results due to the small proportion of $\mathrm{CHNCs}$ which could not interact strongly with the matrices of CA and so future studies are aimed to test the behavior of films formed with a higher fraction of CHNCs in CA matrices.

\section{REFERENCES}

[1] Feng L., Zhou Z., Dufresne A. et al.: Journal of Applied Polymer Science 2009, 112 (5), 2830. https://doi.org/10.1002/app.29731

[2] Chen G., Dufresne A., Huang J., Chang P.R.: Macromolecular Materials and Engineering 2009, 294 (1), 59. https://doi.org/10.1002/mame.200800261

[3] Liu H., Hsieh Y.L.: Journal of Polymer Science Part B: Polymer Physics 2002, 40 (18), 2119. http://dx.doi.org/10.1002/polb.10261

[4] Lv C., Su Y., Wang Y. et al.: Journal of Membrane Science 2007, 294 (1), 68. https://doi.org/10.1016/j.memsci.2007.02.011

[5] Filho G.R., Monteiro D.S., Meireles C.D.S. et al.: Carbohydrate Polymers 2008, 73 (1), 74. https://doi.org/10.1016/j.carbpol.2007.11.010

[6] Kurita K.: Marine Biotechnology 2006, 8 (3), 203. https://doi.org/10.1007/s10126-005-0097-5

[7] De Azeredo H.M.C.: Food Research International 2009, 42 (9), 1240. https://doi.org/10.1016/j.foodres.2009.03.019

[8] Goetz L.A., Jalvo B., Rosal R. Mathew A.P.: Journal of Membrane Science 2016, 510, 238. https://doi.org/10.1016/j.memsci.2016.02.069

[9] Brugnerotto J., Lizardi J., Goycoolea F.M. et al.: Polymer 2001, 42 (8), 3569.
https://doi.org/10.1016/S0032-3861(00)00713-8

[10] Rinaudo M.: Progress in Polymer Science 2006, 31 (7), 603.

https://doi.org/10.1016/j.progpolymsci.2006.06.001

[11] Wang J., Wang Z., Li J. et al.: Carbohydrate Polymers 2012, 87 (1), 784.

https://doi.org/10.1016/j.carbpol.2011.08.066

[12] Watthanaphanit A., Supaphol P., Tamura H. et al.: Journal of Applied Polymer Science 2008, 110 (2), 890. https://doi.org/10.1002/app.28634

[13] Morin A., Dufresne A.: Macromolecules 2002, 35 (6), 2190. http://dx.doi.org/10.1021/ma011493a

[14] Paillet M., Dufresne A.: Macromolecules 2001, 34 (19), 6527.

https://doi.org/10.1021/ma002049v

[15] Nair K.G., Dufresne A.: Biomacromolecules 2003, 4 (3), 657. https://doi.org/10.1021/bm020127b

[16] Junkasem J., Rujiravanit R., Supaphol P.: Nanotechnology 2006, 17 (17), 4519. https://doi.org/10.1088/0957-4484/17/17/039

[17] Lu Y., Weng L., Zhang L.: Biomacromolecules 2004, 5 (3), 1046. http://dx.doi.org/10.1021/bm034516x

[18] Chang P.R., Jian R., Yu J., Ma X.: Carbohydrate Polymers 2010, 80 (2), 420. https://doi.org/10.1016/j.carbpol.2009.11.041

[19] Sriupayo J., Supaphol P., Blackwell J., Rujiravanit R.: Carbohydrate Polymers 2005, 62 (2), 130. https://doi.org/10.1016/j.carbpol.2005.07.013

[20] Butchosa N., Brown C., Larsson P.T. et al.: Green Chemistry 2013, 15 (12), 3404. https://doi.org/10.1039/C3GC41700J

[21] Vieira M.G.A., da Silva M.A., dos Santos L.O., Beppu M.M.: European Polymer Journal 2011, 47 (3), 254. https://doi.org/10.1016/j.eurpolymj.2010.12.011

[22] Ghanbarzadeh B., Almasi H., Entezami A.A.: Innovative Food Science \& Emerging Technologies 2010, $11(4), 697$. https://doi.org/10.1016/j.ifset.2010.06.001

[23] Salaberria A.M., Fernandes S.C.M., Diaz R.H., Labidi J.: Carbohydrate Polymers 2015, 116, 286. https://doi.org/10.1016/j.carbpol.2014.04.047

[24] Mathew A.P., Laborie M.P.G., Oksman K.: Biomacromolecules 2009, 10 (6), 1627. https://doi.org/10.1021/bm9002199

[25] Gaill F., Person J., Sugiyama J. et al.: Journal of Structural Biology 1992, 109 (2), 116. https://doi.org/10.1016/1047-8477(92)90043-A

[26] Chen Y., Liu C., Chang P.R. et al.: Polymer Engineering \& Science 2009, 49 (2), 369. https://doi.org/10.1002/pen.21290

[27] Siqueira G., Bras J., Follain N. et al.: Carbohydrate Polymers 2013, 91 (2), 711. https://doi.org/10.1016/j.carbpol.2012.08.057

[28] Habibi Y., Dufresne A.: Biomacromolecules 2008, 9 (7), 1974. 
https://doi.org/10.1021/bm8001717

[29] Northrop D.M., Rowe W.F.: “Biodeterioration Research 1" (Eds. Llewellyn G.C., O'Rear C.E.), Springer, Boston, MA 1987, pp. 7-16.

https://doi.org/10.1007/978-1-4613-0949-9_3

[30] Bhushan B., Jung Y.C.: Nanotechnology 2006, 17 (11), 2758. https://doi.org/10.1088/0957-4484/17/11/008

[31] Naseri N., Mathew A.P., Girandon L. et al.: Cellulose 2015, 22 (1), 521. https://doi.org/10.1007/s10570-014-0493-y

[32] Li X., Wang K.Y., Helmer B., Chung T.S.: Industrial \& Engineering Chemistry Research 2012, 51 (30), 10039. https://doi.org/10.1021/ie2027052
[33] Rabea E.I., Badawy M.E.T., Stevens C.V. et al.: Biomacromolecules 2003, 4 (6), 1457. https://doi.org/10.1021/bm034130m

[34] Krajewska B., Kyzioł A., Wydro P.: Colloids and Surfaces A: Physicochemical and Engineering Aspects 2013, 434, 359. http://dx.doi.org/10.1016/j.colsurfa.2013.03.018

[35] Kong L.-A., Yang J., Li G.T. et al.: PLoS Pathogens 2012, 8 (2), e1002526. http://dx.doi.org/10.1371/journal.ppat.1002526

[36] Salaberria A.M., Diaz R.H., Labidi J., Fernandes S.C.M.: Food Hydrocolloids 2015, 46, 93. https://doi.org/10.1016/j.foodhyd.2014.12.016

Received 12 V 2020.

\section{W kolejnym zeszycie ukażą się m.in. następujące artykuły:}

N.A. Abdullah, M.S.A. Rani, M. Mohammad, M.H. Sainorudin, N. Asim, Z. Yaakob, H. Razali, Z. Emdadi- Nanoceluloza z odpadów rolniczych jako potencjalny materiał nanotechnologiczny (j. ang.)

Zaręba A. - Nanokompozyty na osnowie polipirolu w ochronie metali przed korozją - przegląd literaturowy N.M. Nurazzi, N.D. Siti Zulaikha, A.B. Norhana, M.I. Syakir, A. Norli-Czujniki na bazie nanorurek węglowych do wykrywania obecności amoniaku - przegląd (j. ang.)

N.A. Abdullah, M.H. Sainorudin, M.S.A. Rani, M. Mohammad, N.H.A. Kadir, N. Asim - Strukturalne, morfologiczne i termiczne właściwości celulozy mikrokrystalicznej pozyskiwanej z włókien łupiny orzecha kokosowego (j. ang.)

M.Y.M. Zuhri, M.A. Nasrudin, M.A.M. Nasrodin, S.M. Sapuan, M.Z. Hassan - Właściwości mechaniczne w warunkach quasi-statycznego obciążenia struktur zazębiających się z kompozytu len/poli(kwas mlekowy) (j. ang.) 